\title{
Analisis Metakognisi Siswa Dalam Memecahkan Masalah Relasi Logik Dan Fungsi Gerbang Logika Ditinjau Dari Tipe Kepribadian Tipologi Hippocrates Galenus
}

\author{
Al'aina Mar'atus Sholikha ${ }^{1}$, Muchamad Arif ${ }^{2}$ \\ Prodi Pendidikan Informatika, Universitas Trunojoyo Madura, Madura, Indonesia \\ email: ${ }^{1}$ alainamsh@gmail.com, ${ }^{2}$ arif@trunojoyo.ac.id
}

\begin{abstract}
Abstrak
Penelitian ini bertujuan untuk mendeskripsikan metakognisi siswa dalam pemecahan masalah pada materi relasi logik dan fungsi gerbang logika berdasarkan tipe kepribadian Hippocrates Galenus yaitu sanguinis, koleris, melankolis, dan plegmatis. Penelitian ini menggunakan pendekatan deskriptif kualitatif. Subjek dalam penelitian ini adalah X C SMK Al Azhar Menganti dengan sampel penelitian menggunakan teknik purposive sampling. Instrumen yang digunakan yaitu kuesioner kepribadian siswa, soal tes esai pemecahan masalah metakognisi dan pedoman wawancara Analisis data yang dilakukan mulai dari pegumpulan data, reduksi, penyajian dan simpulan. Triangulasi yang digunakan adalah teknik, dan waktu. Hasil dari penelitian ini menunjukkan bahwa siswa dengan tipe kepribadian sanguinis dan koleris berada pada tingkat metakognisi aware use. Siswa dengan tipe kepribadian melankolis berada pada tingkat metakognisi reflective use. Sedangkan siswa dengan tipe kepribadian plegmatis berada pada tingkat metakognisi strategic use.
\end{abstract}

Kata Kunci: Metakognisi, Pemecahan Masalah, Kepribadian Hippocrates Galenus, Sistem Komputer.

\begin{abstract}
This study aims to describe students' metacognition in problem solving on the material of logical relations and logic gate functions based on the personality type of Hippocrates Galenus, namely sanguinis, choleric, melancholic, and phlegmatic. This research use desciptive qualitative approach. The subjects in this study were $X$ C SMK Al Azhar Menganti with the research sample using purposive sampling technique. The instruments used were student personality questionnaires, metacognition problem-solving essay tests and interview guidelines. Data analysis was carried out starting from data collection, reduction, presentation and conclusion. The triangulation used is technique, and time. The results of this study indicate that students with sanguine and choleric personality types are at the level of aware use metacognition. Students with melancholic personality type are at the level of reflective use metacognition. Meanwhile, students with the phlegmatic personality type are at the level of strategic use metacognition.
\end{abstract}

Keywords: Metacognition, Problem Solving, Hippocrates Galenus Personality, Computer Systems. 


\section{PENDAHULUAN}

Salah satu peran yang paling penting dalam mengembangkan sumber daya manusia adalah pendidikan. Pendidikan yang berkualitas manusia dapat menjadi pusat ujung tombak kemajuan suatu negara. Beberapa negara yang digdaya seperti China, Amerika, Inggris, Jerman dan negara tetangga kita seperti Singapura, Taiwan dan lain-lain. Negara-negara tersebut menjadikan pendidikan sebagai faktor strategis dalam memajukan bangsanya. Pendidikan yang berkualitas dapat menciptakan sumber daya manusia yang produktif dan berkualitas. Keberhasilan suatu bangsa dalam membangun sebuah pendidikan merupakan parameter tingkat kemajuan bangsa tersebut. Pada era Society 5.0 teknologi digital memiliki peran pusat dalam segala aktivitas kehidupan. Oleh karena itu penggunaan teknologi pada pendidikan dituntut untuk terus berkembang. Dengan adanya hal ini, pendidikan Sekolah Menengah Kejuruan (SMK) menuntut memiliki kemampuan untuk terjun di dunia industri, usaha, maupun teknologi.

Hal yang harus dipersiapkan dalam menghadapi di dunia industri, usaha, maupun teknologi adalah kualitas peserta didik dan lembaga Pendidikan, sehingga proses pendidikan dapat mendukung terlaksananya target-target pemerintah. Sekolah merupakan lembaga pendidikan yang di dalamnya terjadi proses belajar mengajar, proses mendidik dan semua proses yang memiliki keterkaitan dengan kegiatan belajar mengajar dan menghasilkan output berdasarkan kurikulum yang berlaku. Di samping itu, kesiapan dan kelengkapan sekolah dalam menghadapi berbagai tantangan yang ada, salah satunya kesiapan dalam kegiatan belajar mengajar (KBM).

Untuk mengetahui bagaimana proses belajar mengajar (KBM) yang terjadi saat ini maka dilakukanlah observasi di SMK Al Azhar Menganti. Berdasarkan hasil wawancara pada tanggal 25 febuari 2021 dengan guru mata pelajaran sistem komputer kelas X TKJ SMK Al Azhar Menganti yaitu bapak Muhammad Maulana Ilham, S.Pd dapat dipaparkan bahwa hasil tugas dari guru dan pengamatan guru, siswa diwajibkan mencatat, karena mencatat materi dijadikan syarat memasuki kelas sebelum pembelajaran dimulai. Namun, untuk proses membaca, mengamati permasalahan, melakukan analisis, eksplorasi, pelaksanaan, dan pemeriksaan kembali hanya mampu dilakukan sekitar 3 siswa saja dalam satu kelas. Hal ini selain didapatkan dari pengamatan oleh guru selama mengajar, juga dapat dihubungkan dengan prestasi belajar siswa belum menunjukkan bahwa beberapa siswa memiliki kemampuan metakognisi. Sedangkan pengamatan mengenai kepribadian, tingkah laku siswa belum bisa terlihat secara maksimal. Hal ini dikarenakan pembelajaran berlangsung selama 6 bulan yang dilakukan secara online. Hasil pengamatan perilaku dengan teman juga terbatas karena sistem pembelajaran daring (dalam jaringan) yang mengharuskan memasuki kelas secara bergilir. Guru menjelaskan bahwa perbedaan waktu memasuki kelas pada hari-hari tertentu yang diizinkan untuk mengikuti pembelajaran secara offline, yaitu secara bergilir dengan dibedakan menjadi dua gelombang, presensi ganjil dan genap selama proses pembelajaran sistem komputer.

Mata pelajaran sistem komputer merupakan salah satu mata pelajaran produktif yang memiliki peran penting dalam perkembangan teknologi. Pada mata pelajaran sistem komputer ini membahas dasar matematika dan fisika, dan proses input dan output berupa informasi. Kemampuan dasar yang harus dimiliki siswa adalah kemampuan memecahkan masalah. Pada penelitian Putri (dalam Elita dkk 2019: 448) menuturkan bahwa pemecahan masalah merupakan proses dalam mengatasi kesulitan-kesulitan yang dihadapi dan untuk mencapai tujuan yang diharapkan. Dalam mencapai tujuan pembelajaran, maka dibutuhkan beberapa indikator. Kemampuan memecahkan masalah memiliki beberapa indikator menurut Polya (dalam Ihsan 2018: 130) meliputi identifikasi masalah, merencanakan penyelesaian, menyelesaikan masalah, dan menginterpretasikan hasil yang diperoleh.

Kemampuan menyelesaikan masalah dalam mempelajari materi relasi logik dan fungsi gerbang logika membutuhkan pola pikir yang sistematis dan kritis. Pola pikir yang sistematis dan kritis digunakan untuk menalar dalam mengimplementasikan dasar matematika dan fisika dalam materi fungsi relasi logik dan fungsi gerbang logika. Dalam mengontrolnya siswa memerlukan strategi belajar materi

74 | Analisis Metakognisi Siswa Dalam Memecahkan Masalah Relasi Logik Dan Fungsi Gerbang Logika Dit... 
tersebut, siswa harus mengetahui proses metakognisi dalam dirinya. Hal ini sejalan dengan pendapat Ihsan (2018) bahwa tinggi rendahnya kemampuan dalam pemecahan masalah dipengaruhi oleh beberapa faktor diantaranya adalah metakognisi, motivasi belajar, dan kreativitas belajar siswa. Menurut pendapat Ozsoy, G. \& Ataman (2013: 63) menerangkan kalau pemecahan permasalahan yang efisien dapat diperoleh melalui pemanfaatan kemampuan metakognisi.

Menurut Livingstone dalam Purnomo (2018: 19) metakognisi merupakan think about thinking atau berpikir tentang berpikir. Dengan definisi lain bahwa metakognisi merupakan kemampuan berpikir seseorang tentang apa yang dipikirkannya. Beberapa pengertian lain tentang metakognisi menjelaskan antara lain yaitu menurut Wellman (dalam Chairani 2015: 202) metakognisi merupakan bentuk kognisi, yaitu suatu proses berpikir tingkat tinggi yang melibatkan kontrol secara aktif selama melakukan kegiatan kognisi.

Pengetahuan metakognisi terdiri dari tiga sub jenis yaitu: (1) pengetahuan strategis. Pengetahuan strategis merupakan pengetahuan tentang strategi-strategi belajar yang digunakan untuk melakukan proses belajar, berpikir dan pemecahan masalah. (2) Pengetahuan mengenai tugas-tugas yang berkaitan dengan kognitif yang, meliputi pengetahuan kontekstual dan kondisional, dalam pengetahuan strategi siswa yang dapat digunakan pada strategi belajar untuk menghafal materi pelajaran, mencari makna teks, atau memahami informasi yang didengar baik proses belajar di dalam dari buku atau bahan ajar lainnya. (3) Pengetahuan tentang diri yang mempengaruhi kinerja belajar terkait pemahaman siswa yang tidak bisa langsung untuk memahami apa yang dijelaskan guru disebabkan oleh keterbatasan pemikiran.

Keterbatasan pemikiran terjadi dikarenakan siswa belum merasa sadar tentang aktivitas pembelajarannya yang memiliki ketidakmampuan dalam menyelesaikan soal. Maka perlu adanya penelitian sejauh mana kemampuan yang dimiliki siswa dalam memecahkan masalah. Hal ini sama dengan kemampuan metakognisi memerlukan kesadaran terhadap kemampuannya untuk mengembangkan cara apa saja yang digunakan dalam memecahkan masalah. Kesadaran menunjukan seberapa jauh kemampuan siswa dapat memecahkan masalah. Maka, dapat dilakukan analisis tingkat metakognisi yang muncul pada siswa. Tingkat metakognisi dapat diketahui berdasarkan karakteristik metakognisi yang ada pada pribadi siswa. Tingkat metakognisi dibedakan menjadi 4 oleh Swartz dan Perkenis (dalam Fisher 1998: 8) yaitu: penggunan tanpa kesadaran (tacit use), Penggunaan dengan kesadaran (aware use), penggunaan strategi (strategic use), penggunaan reflektif (reflective use).

Adanya tingkat metakognisi diatas menunjukkan bahwa tingkat kesadaran setiap individu berbeda-beda. Hal tersebut berpengaruh pada strategi untuk pemecahan masalah. Pada hasil penelitian terdahulu menyatakan bahwa kemampuan kognitif dalam menyelesaikan masalah bukan menjadi satusatunya yang memiliki pengaruh pada hasil belajar siswa. Hal ini sama dengan pendapat yang diungkapkan oleh Furnham dkk (dalam Rosito 2018: 7) menyatakan bahwa aspek motivational yang berasal dari kepribadian individu yang ditemukan berpengaruh besar terhadap prestasi siswa. Aspek motivational individu merupakan fitur dari karakteristik kepribadian yang dapat menggambarkan kemampuan atau dorongan yang kuat seseorang dalam tindakannya. Teori kepribadian yang digunakan adalah adalah tipe kepribadian tipologi hippocrates -galenus yang terdiri dari tipe sanguinis, choleris, melancholis, plegmatis.

Kepribadian adalah bagian latar belakang seseorang terhadap sikap-sikap terhadap perilakunya. Tipe kepribadian tipologi hippocrates galenus. Menurut Tan (dalam Amalia \& Isnaini 2019: 194) tipe kepribadian tipologi Hippocrates Galenus adalah salah satu tipe kepribadian dikatakan oleh Socrate dan Galenus lebih dari 400 tahun sebelum masehi. Tipe kepribadian hippocrates galenus dari ahli terdahulu menyatakan bahwa ada empat dasar yang terdiri dari empat temperamen. Tipe temperamen itu terdiri dari zat-zat cair dari dalam tubuh manusia yang memiliki ciri khas atau keunikan sendirisendiri. Diantaranya adalah koleris (empedu kuning) termasuk jenis tipe kepribadian yang sering merasa bersemangat terhadap segala hal. Tipe kepribadian melankolis (empedu hitam) termasuk tipe 
kepribadian yang mudah kecewa, pesimis, perfeksionis, rapi, kaku dan pemikir. Tipe kepribadian sanguinis (darah merah) tipe kepribadian yang periang, lincah, tidak mudah putus asa, mudah senyum dan supel. Namun lebih moody dan kurang produktif. Tipe kepribadian plegmatis yang tidak suka tergesa-gesa, setia, tidak mudah dipengaruhi oleh lingkungan, tidak peduli dengan beberapa keadaan tertentu, santai, dan sabar.

\section{METODE PENELITIAN}

Dalam penelitian ini, peneliti menggunakan metode penelitian kualitatif. Menurut pendapat Sugiarto (2015: 8) menjabarkan bilamana metode penelitian kualitatif merupakan penelitian yang tidak memerlukan proses statistik atau proses perhitungan yang berpola dan memiliki tujuan untuk mengungkapkan gejala secara holistik-kontekstual yang didapat melalui data atau fakta-fakta yang terkumpul dari kondisi alamiah dan menjadikan peneliti sebagai kunci instrumen penelitian. pendekatan kualitatif deskriptif yang bertujuan untuk mendeskripsikan tingkat kemampuan siswa dalam menyelesaikan masalah relasi logik dan fungsi gerbang logika ditinjau dari tipe kepribadian tipologi hiprcrates galenus siswa kelas X TKJ C di SMK Al Azhar Menganti.

Penelitian ini dilakukan analisis yang mendalam untuk mengetahui tipe kepribadian siswa dapat dilihat melalui kuesioner kepada subjek penelitian. Peneliti menetapkan teknik pengambilan sampel yaitu Purposive Sampling. Purposive Sampling merupakan teknik pengambilan sampel sumber data yang dilakukan dengan pertimbangan tertentu. Dalam memmilih subjek penelitian yang menjadi dasar peeliti dalam menentukannya adalah bersumber dari Hamidah (2018:19) yang berpendapat bahwa subjek penelitian yang diambil adalah siswa yang paling banyak memilih penyataan paling banyak dalam masing-masing tipe kepribadian dan yang paling komunikatif berdasarkan hasil diskusi dari guru produktif. Instrumen dalam penelitian ini adalah lembar tipe kepribadian siswa (segi kelemahan dan kekuatan), lembar soal tes esai metakognisi siswa, dan wawancara. Sehingga dalam hal ini peneliti menggunakan triangulasi teknik dan waktu.

\section{HASIL DAN PEMBAHASAN}

Berdasarkan hasil dari penelitian yang didapatkan dari hasil kuesioner kepribadian dan rekomendasi guru produktif, peneliti mendapatkan hasil sebagai berikut:

1. Eka Fitriani memiliki tipe kepribadian sanguinis dengan poin sebesar 20.

2. Mochamad Ongki Ramadani memiliki tipe kepribadian koleris dengan poin sebesar 16.

3. Esalina Prisa Wanudia, memiliki tipe kepribadian melankolis dengan poin sebesar 18.

4. Safira Aulianisa, memiliki tipe kepribadian plegmatis dengan poin sebesar 23.

Setelah menapatkan 4 sampel dari setiap tipe kepribadian, kemudian peneliti memberikan soal tes esai pemecahan masalah relasi logik dan fungsi gerbang logika dengan indikator metakognisi merencanakan pemecahan masalah, melaksanakan pemecahan masalah, dan memeriksa kembali/ evaluasi. Setelah hasil diperoleh maka peneliti menganalisis secara mendalam tingkat metakognisi setiap indikator sehingga diperoleh hasil akhir tingkat metakognisi secara keseluruhan sebagai berikut:

1. Tingkat metakognisi STS dapat ditentukan bilamana aktivitas metakognisi setiap tahap pada masing-masing soal diketahui dengan detail. Jika ada tingkat metakognisi yang berbeda pada setiap tahap, dilakukan kajian dan analisis yang mendalam serta menitikberatkan pemahaman konsep dasar kemudian penjelasan sampel STS. Dalam hal ini STS berada pada tingkat aware use. STS dapat memahami konsep dasar, membuat perencanaan yang cukup matang dan memahami permasalahan. Namun, STS kurang teliti dan seringkali tidak melakukan evaluasi dengan baik, sehingga terjadi kesalahan yang tidak dapat diperbaiki.

76 | Analisis Metakognisi Siswa Dalam Memecahkan Masalah Relasi Logik Dan Fungsi Gerbang Logika Dit... 
2. Tingkat metakognisi STK dapat ditentukan bilamana aktivitas metakognisi setiap tahap pada masing-masing soal diketahui dengan detail. Jika ada tingkat metakognisi yang berbeda pada setiap tahap, dilakukan kajian dan analisis yang mendalam serta menitikberatkan pemahaman konsep dasar kemudian penjelasan sampel STK. Dalam hal ini STK berada pada tingkat aware use. STK dapat memahami konsep dasar, membuat perencanaan yang cukup,dan memahami permasalahan. Namun, STK kurang teliti dan seringkali tidak melakukan evaluasi dengan baik, sehingga terjadi kesalahan yang tidak diperbaiki, hanya mampu menyelesaikan soal, jika pernah mendapatkan soal serupa sebelumnya.

3. Tingkat metakognisi STM dapat ditentukan bilamana aktivitas metakognisi setiap tahap pada masing-masing soal diketahui dengan detail. Jika ada tingkat metakognisi yang berbeda pada setiap tahap, dilakukan kajian dan analisis yang mendalam serta menitikberatkan pemahaman konsep dasar dan penjelasan sampel STM. Dalam hal ini tingkat metakognisi STM berada pada tingkat yang sama secara keseluruhan yaitu reflective use. Sehingga tidak perlu dilakukan kajian dan analisis yang mendalam secara berulang, karena tingkat metakognisi sampel STM secara otomatis berada pada tingkat reflective use.

Tingkat metakognisi STP dapat ditentukan bilamana aktivitas metakognisi setiap tahap pada masing-masing soal diketahui dengan detail. Jika ada tingkat metakognisi yang berbeda pada setiap tahap, dilakukan kajian dan analisis yang mendalam serta menitikberatkan pemahaman konsep dasar kemudian penjelasan dari sampel STP. Dalam hal ini tingkat metakognisi STP berada pada tingkat yang berbeda. Sehingga perlu dilakukan kajian, dan analisis mendalam secara berulang. Untuk mendapatkan kesimpulan yang tepat. Ulasan terhadap hasil dari data soal tes esai dan wawancara menjadi poin penting dalam mengambil keputusan. Data wawancara STP soal nomor 1, pada semester sebelumnya soal serupa seringkali dikerjakan. Sehingga hal ini ada keterkaitan pemahaman sebelumnya. Jadi STP berpatokan hanya pada pemahaman yang sering kali diulang-ulang. Sedangkan pada soal nomor 2, pada tahap wawancara STP menjelaskan bahwa soal nomor 2 belum diketahui sebelumnya. Sehingga dari hasil data inilah didukung dengan data dan fakta lainnya seperti 1 varian saja yang mampu dijelaskan pada soal nomor 2. STP hanya mampu memilih strategi penyelesaian yang membutuhkan waktu lebih lama, meskipun jawabannya selama tahap pemantauan dan evaluasi adalah detail. STP dapat dinyatakan berada pada tingkat strategic use.

\section{KESIMPULAN}

Siswa dengan tipe kepribadian sanguinis berada pada tingkat aware use. Dengan aktivitas metakognisi mampu memahami permasalahan dan solusi, meskipun dengan beberapa penjelasan yang belum detail. Mampu merencanakan strategi, meskipun strategi yang digunakan hanya 1 saja. Pada tahap pemantauan, dan evaluasi belum dilakukan secara tepat, dan teliti. Siswa dengan tipe kepribadian koleris, berada pada tingkat aware use. Dengan aktivitas metakognisi mampu memahami permasalahan dan solusi, meskipun hanya pada soal serupa yang pernah dikerjakan sebelumnya dan beberapa penjelasan yang belum detail. Mampu merencanakan strategi, meskipun strategi yang digunakan hanya 1 saja. Pada tahap pemantauan dilakukan tidak sesuai dengan kebutuhan penyelesaian. Pada tahap evaluasi, subjek memaksakan jawaban yang tepat yang kurang sesuai dengan hasil penyelesaian.

Siswa dengan tipe kepribadian melankolis berada pada tingkat metakognisi reflective use. Dengan aktivitas metakognisi, mampu memahami soal dan solusi dengan baik dan benar. Mampu merencanakan dengan sangat tepat dan menguasai beberapa strategi lainnya. Mampu melaksanakan strategi dengan benar, cepat, dan mampu melakukan evaluasi dengan hati-hati. Sehingga tidak terjadi kesalahan di dalamnya. Meskipun selama proses perencanaan lebih lama daripada proses pemantauan dan evaluasi. Siswa dengan tipe kepribadian plegmatis, berada pada tingkat metakognisi strategic use. Dengan aktivitas metakognisi, mampu memahami soal dan solusi dengan tepat. Mampu membuat 
perencanaan dengan tepat dan mengetahui cara beberapa strategi lainnya. Selama tahap pemantauan subjek sangat maksimal pada soal serupa yang sudah pernah dikerjakan sebelumnya, sedangkan pada soal yang baru ditemui, proses penyelesaian benar, namun belum maksimal. Pada tahap evaluasi dilakukan dengan benar, detail dan hati-hati.

Dalam penelitian ini terdapat beberapa saran yang diharapkan akan membantu pihak-pihak terkait, saran dari peneliti. Bagi guru hendaknya lebih memperhatikan tingkat dan aktivitas metakognisi siswa, meskipun kondisi saat ini berbeda dengan kondisi sebelumnya. Sehingga siswa akan lebih menguasai pada bidangnya (TKJ). Guru juga memperhatikan kembali tipe kepribadian yang dimiliki oleh siswa-masing-masing. Tipe kepribadian yang berbeda akan menghasilkan tingkat dan aktivitas metakognisi yang berbeda, sehingga perlu perlakuan yang berbeda pada proses pembelajaran.

Siswa dengan tipe kepribadian sanguinis, dan koleris lebih memperhatikan kembali aktivitas evaluasi. Karena pada tipe kepribadian sanguinis dan koleris merasa kesulitan melakukan evaluasi, bilamana melakukan evaluasi, proses evaluasi masih kurang tepat. Siswa dengan tipe kepribadian plegmatis, selama proses penyelesaian, bisa merencanakan waktu dengan baik. Sehingga tidak membutuhkan waktu yang cukup lama dalam menyelesaikan soal. Siswa dengan tipe kepribadian melankolis, meskipun berada pada tingkat tertinggi, diharapkan bisa lebih mempersingkat waktu aktivitas perencanaan. Untuk peneliti selanjutnya, bisa menjabarkan dengan tingkat metakognisi yang lebih detail (tacit use, aware use, semi strategic use, strategic use, semi reflective use, dan reflective use). Sehingga pada peneliti berikutnya mampu menempatkan siswa pada tingkat metakognisi yang lebih akurat.

\section{DAFTAR PUSTAKA}

Amalia, S. R. (2019). Representasi Matematis dalam Pembelajaran dengan Model Problem-Based Learning Berbasis Etnomatematika ditinjau dari Tipe Kepribadian. Jurnal Elemen, 5(2), 190-205.

Chairani, Z. (2015). Perilaku Metakognisi Siswa dalam Pemecahan Masalah Matematika. Math Didactic: Jurnal Pendidikan Matematika, 1(3), 200-210.

Elita, G. S., Habibi, M., Putra, A., \& Ulandari, N. (2019). Pengaruh Pembelajaran Problem Based Learning dengan Pendekatan Metakognisi terhadap Kemampuan Pemecahan Masalah Matematis. Mosharafa: Jurnal Pendidikan Matematika, 8(3), 447-458.

Fisher, R. (1998). Thinking About Thinking: Developing Metacognition in Children. Early Child Development and Care, 141(1), 1-15.

Hamidah, N. (2018). Kecerdasan Visual-Sapsial Siswa ditinjau dari Tipe Kepribadian HippocratesGalenus. Universitas Jember.

Ihsan, M. (2018). Pengaruh Metakognisi dan Motivasi terhadap Kemampuan Pemecahan Masalah Matematika Melalui Kreativitas Siswa Kelas VIII SMP Negeri di Kecamatan Kindang Kabupaten Bulukumba. Al-Khwarizmi: Jurnal Pendidikan Matematika Dan Ilmu Pengetahuan Alam, 4(2), 129-140.

Ozsoy, G. \& Ataman, A. (2013). The Effect of Metacognitive Strategy Training Mathematical Problem Solving and Achievement. Journal of Psychology \& Psychotherapy, 03(04).

Purnomo, D. (2018). Pola dan Perubahan Metakognisi dalam Pemecahan Masalah Matematis. In Journal of Chemical Information and Modeling (1st ed.). Malang: Media Nusa Creative.

Rosito, A. C. (2018). Eksplorasi Tipe Kepribadian Big Five Personality Traits dan Pengaruhnya 78 | Analisis Metakognisi Siswa Dalam Memecahkan Masalah Relasi Logik Dan Fungsi Gerbang Logika Dit... 
Terhadap Prestasi Akademik. Jurnal Psikologi Pendidikan Dan Konseling: Jurnal Kajian Psikologi Pendidikan Dan Bimbingan Konseling, 4(1), 6-12.

Sugiarto, E. (2015). Menyusun Proposal Penelitian Kualitatif: Skripsi dan Thesis (Pertama). Yogyakarta: Suaka Media. 
